九州大学学術情報リポジトリ

Kyushu University Institutional Repository

\title{
Meta-Evidence of Asymmetric Price Transmission in US Agricultural Markets
}

Zheng, Shi

School of Business, Renmin University of China

Miller J. Douglas

Department of Economics, University of Missouri-Columbia

Wang, Zhigang

School of Agricultural Economics and Rural Development, Renmin University of China

Kai, Satoshi

Department of Agricultural and Resource Economics, Kyushu University

https://doi.org/10.5109/10112

出版情報：九州大学大学院農学研究院紀要. 53 (1)，pp.349-356，2008-02-28. Faculty of Agriculture, Kyushu University

バージョン :

権利関係 : 


\title{
Meta-Evidence of Asymmetric Price Transmission in US Agricultural Markets
}

\author{
Shi ZHENG ${ }^{1}$, Douglas J. MILLER ${ }^{2}$, Zhigang WANG ${ }^{3}$ \\ and Satoshi KAI ${ }^{4 *}$
}

\author{
${ }^{1}$ School of Business, Renmin University of China, P. R. China \\ ${ }^{2}$ Department of Economics, University of Missouri - Columbia, USA \\ ${ }^{3}$ School of Agricultural Economics and Rural Development, \\ Renmin University of China, P. R. China \\ ${ }^{4}$ Laboratory of Food Marketing, Division of Industrial Organization of Agribusiness, \\ Department of Agricultural and Resource Economics, Kyushu University, \\ Fukuoka 812-8581, Japan \\ (Received November 9, 2007 and accepted November 30, 2007)
}

\begin{abstract}
In this paper, we examine the evidence of asymmetric price transmission in several important US agricultural markets. We use estimated asymmetric error correction models (ECM) for producer, wholesale, and retail prices to test the presence of asymmetric price transmission. Following several other studies reported in this literature, we find mixed evidence of the phenomenon across the candidate markets. We then summarize the test results by conducting a meta-analysis of the p-values associated with the observed asymmetry test statistics. We find that the p-values associated with the beef market are significantly less than the base markets, and there is evidence that the test p-values are slightly higher in later years (since 1990).
\end{abstract}

\section{INTRODUCTION}

The relationship between farm, wholesale, and retail food prices has important economic and political implications, and price outcomes in these vertically related markets have been studied by agricultural economists for several years. Although the general theory of crossmarket price relationships is well established, there still exist some unresolved issues related to observed price behavior. One key area for ongoing research is related to asymmetric price transmission, which refers to the phenomenon that downstream (e.g., retail) prices respond to upstream (e.g., farm) price increases and decreases at different rates. Typically, wholesale or retail prices respond more quickly when farm prices are rising than when farm prices are falling. For example meat producers sometimes complain that retailers quickly increase meat prices as farm prices rise, but do not reduce retail meat prices as quickly when farm prices drop. Although asymmetric pricing is typically associated with isolated incidents, especially when farm prices are low (e.g., hog prices in December, 1998), the statistical evidence points to more subtle yet pervasive differences in the ways downstream prices respond to upstream price changes.

The previously published studies also report mixed evidence on the presence of asymmetric price transmission, and the findings vary by product and over time. Further, some of the published findings report regional differences in the pattern of asymmetric price transmission for particular products (e.g., Willett, Hansmire, and Bernard, 1997). Consequently, researchers have found it very difficult to characterize or understand asymmetric price transmission in terms of differences among the

\footnotetext{
* Corresponding author (E-mail: satokai@agr.kyushu-u.ac.jp)
}

products (e.g, location of production, degree of perishability) or the markets (e.g., location, concentration of the wholesale or retail markets, coverage by marketing orders).

The objective of the paper is to conduct a metaanalysis of the evidence related to asymmetric price transmission in several important US agricultural product markets. Although the meta-analysis may be based on the previously published findings, this approach may be subject to substantial unexplained variation due to differences in the modeling and estimation methods, sample period selection, and testing criteria. In order to reduce the impact of these influences, we analyze the observed price data using a comparable set of models and methods. In particular, we focus on agricultural price outcomes at the farm $\left(\mathrm{F}_{\mathrm{t}}\right)$, wholesale $\left(\mathrm{W}_{\mathrm{t}}\right)$, and retail $\left(R_{t}\right)$ levels, and the prices are defined for comparable quantities (e.g., retail pounds). We include several agricultural products that have been previously studied (e.g., beef, pork, poultry, eggs, and milk) as well as other farm products that have received less attention in the literature (e.g., lemons, potatoes, and tomatoes). We also consider lemon price data for three regional markets (West, South, and North Central) in order to study the regional pattern of asymmetric price transmission in the United States. To ensure comparability of the findings, we use monthly data and similar econometric model specifications for all products. We review of the relevant literature in the following section, the estimation and asymmetry testing results are presented in Section 3, and the meta-analysis is discussed in Section 4. Concluding remarks are provided in the last section. 
The asymmetric pricing phenomenon has been observed in a wide range of agricultural and non-agricultural markets and there are several plausible causes. In a perfectly competitive market, the marketing margin between two market levels represents the marginal cost (supply) of these marketing activities. Although marketing costs are expected to change as the quantity of product flowing through the marketing channel changes, the changes in the marketing costs are typically assumed to be the same as quantity increases or decreases. However, if these marketing costs are asymmetric, they may serve as one potential source of asymmetric price transmission.

Economists have also identified other potential reasons for asymmetric price transmission. In particular, Blinder, Canetti, Lebow and Rudd (1998) present several plausible reasons, and some of the more prominent explanations include:

(1) Given some degree of market power, retailers and processors may maintain their prices and earn economic rents when their input prices decrease. For oligopolistic sellers, the old output price may serve as a natural focal point. Sellers may choose to maintain the prior price until demand conditions change, like a drop in sales, which suggests price cutting by rivals and justifies a price reduction as an optimal competitive response (Borenstein, Cameron and Gilbert (1997)).

(2) Menu costs may be another cause of asymmetry (Ball and Mankiw (1994)). Menu costs refer to the real resources needed to change the nominal prices (for example, labor and printing costs). Ball and Mankiw state that in most modern economies there is positive trend inflation, and firms' real prices naturally decline over time. In this environment, positive upstream price shocks lead to larger downstream price responses than under negative upstream shocks, and the optimal pricing strategy for firms is to respond asymmetrically to the shocks.

(3) Production lags and inventory management practices may also cause price asymmetry. If production capacities and schedules cannot be adjusted in the very short run (as in many farm product markets), processors and retailers may not decrease their prices as input prices fall in order to maintain adequate inventory levels. Reagan and Weitzman (1982) present a related model with asymmetric inventory adjustment costs due to the non-negativity constraint on inventories. They observe that prices should respond more to situations of excess demand than to excess supply in the short run because competitive firms have greater ability and incentives to respond with inventory adjustment in the case of excess supply.

(4) Search costs associated with asymmetric information may lead to asymmetric price adjustment (Bénabou and Gertner (1993)). Although most retail food prices are more stable than the prices of the associated farm inputs, they tend to be more volatile than other retail products, and this volatility implies low returns and high costs for search. Further, consumers may not have full information about the prices of prod- ucts at the relevant supermarkets. Consequently, sellers may take advantage of this information asymmetry and retain their old retail price when the wholesale price decreases. Further, consumers may form habits and tend to shop certain stores for food products, so changing shopping habits may be costly for consumers. If price differences are small, or are believed by consumers to be small, consumers may ignore the price changes and maintain their shopping routines. Hence, firms with local market power may exploit their asymmetric information to increase margins and cause price asymmetries.

The key point to note here is that there are several potential causes of asymmetric price transmission. Further, we are unlikely to be able to determine the particular cause of an observed asymmetry. Given that some of these reasons are more plausible in some markets than in others, we may be able to examine the findings from several studies of asymmetric price transmission to compare the possible cases.

\section{Previous Empirical Evidence}

Economists have conducted hypothesis tests for asymmetric price transmission in several agricultural product markets using different methods and data, and they have generally reached different conclusions. Given the considerable importance of beef and pork in the US food marketing system, much research effort has been devoted to understanding price transmission across levels of those markets. For example, Boyd and Brorsen (1988) find that wholesale pork prices respond similarly to farm pork price decreases and increases, and pork retailers respond to wholesale pork price increases and decreases in ways that are not significantly different. Schroeder (1988) investigated price transmission for specific pork cuts between wholesale and retail markets. Although there is some evidence that retailers respond more quickly to increasing wholesale prices than decreasing wholesale prices, the cumulative effects are very similar. More recently, Miller and Hayenga (2001) test the symmetry of high- and low-frequency cycles in weekly pork prices. They conclude that wholesale price changes are asymmetrically transmitted to retail prices in relatively low-frequency cycles, while farm pork prices are asymmetrically transmitted to wholesale prices at all frequencies. Although much of this research focuses on asymmetric pricing across vertical market levels, Bailey and Brorsen (1989) investigate spatial pricing in fed cattle markets. They find that spatial price adjustments in fed cattle markets are asymmetric, and prices in other markets reacted more quickly to positive Texas Panhandle price changes than to negative price changes.

Researchers have examined other agricultural product markets for asymmetric price transmission. Ward (1982) showed that wholesale fresh vegetable price decreases are reflected at the retail level more quickly than wholesale price increases, and wholesale price decreases are more fully transmitted to the shipping point (farm) level relative to wholesale price increases. This asymmetric price adjustment pattern is distinctly 
different from the typical pattern. Kinnucan and Forker (1987) examine farm-retail price transmission in the dairy sector and find significant evidence of asymmetric pricing. Other farm product examples include the papers by Abdulai (2002); Azzam (1999); Bernard and Willett (1996); Bunte and Peerlings (2003); Goodwin and Holt (1999); Powers (1995); Romain, Doyon, and Figon (2002); Serra and Goodwin (2003); and Willett, Hansmire, and Bernard (1997). Finally, research on asymmetric price transmission in non-agricultural product markets has largely focused on gasoline prices. These studies include Borenstein, Cameron and Gilbert (1997); Balke, Brown and Yücel (1998); Brown and Yücel (2000); Balke, Brown and Yücel (2002); Eckert (2002); and Bettendorf, Geest and Varkevisser (2003).

\section{ESTIMATION AND TESTING ISSUES}

\section{Error Correction Models}

In general, the theory of vertically related markets implies that farm, wholesale, and retail prices for agricultural products are linked through a long-run equilibrium relationship. Consequently, the price series may be non-stationary and cointegrated (Engle and Granger, 1987). To test the price series for unit roots, we use the Augmented Dickey-Fuller (ADF) test (Said and Dickey, 1984), which is an extension of the Dickey-Fuller test (Dickey and Fuller, 1979) that is asymptotically valid for a general autoregressive moving average (ARMA) process of unknown order. The ADF unit root tests for the farm, wholesale and retail price series are based on three lags, which is generally enough for price adjustment and pass-through to be complete based on the findings reported in the previous research. Given the possibility of seasonal unit roots, we also conduct the seasonal unit root test proposed by Dickey, Hasza and Fuller (1984) for each product. The DHF test is very similar to $\mathrm{ADF}$ test but is based on 12-month differences rather than one-month differences. As in the ADF case, the number of lags included should be large enough so that the residuals are white noise.

If the vertically related price series are mutually non-stationary and integrated of the same order, we use the observed price levels to estimate the cointegrating relationship. For example, the cointegrating equation is $R_{t}=\beta_{0}+\beta_{1} W_{t}+\varepsilon_{t 1}$ for the retail-wholesale relationship and $W_{t}=\beta_{0}+\beta_{1} F_{t}+\varepsilon_{t 2}$ for the wholesale-farm relationship, and we use these fitted models to conduct the cointegration test under the Phillips-Perron z test procedure.

For cointegrated series, error correction (EC) models are commonly used to represent the long-run equilibrium relationships among the vertically related prices. The specification of the short-run components in the EC models depends on the causal structure among the price series, and we use the Granger causality test to determine the causal linkages among the farm, wholesale, and retail price series for each product. For example, the causal relationship among wholesale and retail prices is examined by conducting an $\mathrm{F}$-test based on the model

$$
R_{t}=\alpha+\beta_{1} W_{t-1}+\beta_{2} W_{t-2}+\gamma_{1} R_{t-1}+\gamma_{2} R_{t-2}+\varepsilon_{t}
$$

under the null hypothesis $H_{0}: \beta_{1}=\beta_{2}=0$. If the coefficients on the lagged wholesale prices are jointly significant, the wholesale prices cause, in the Granger sense, the retail prices. Given that we use monthly price data, feedback from downstream prices to upstream prices may exist and is tested under the Granger criterion.

Based on the observed diagnostic test outcomes, we specify an EC model that allows for potential asymmetric price transmission in the short-run components of the model. For example, the retail-wholesale price relationship may be evaluated with

$$
\begin{aligned}
\Delta R_{t}= & \alpha+\beta_{1} \Delta R_{t-1}+\beta_{2} \Delta R_{t-2}+\beta_{3} \Delta W_{t}+\beta_{4} \Delta W_{t-1} \\
& +\beta_{5} \Delta W_{t-2}+\beta_{6} \Delta R_{t-1}^{+}+\beta_{7} \Delta W_{t}^{+}+\beta_{8} \Delta W_{t-1}^{+} \\
& +\gamma\left(W_{t-1}-v R_{t-1}\right)+\sum_{i=1}^{11} \delta_{i} D_{i}+\varepsilon_{t}
\end{aligned}
$$

Here, the current change in retail prices depends on preceding lags in retail price changes, the current and lagged changes in the wholesale price, the asymmetry terms, the error correction term, and a set of monthly dummy variables. Note that the asymmetry terms are based on the Heaviside function such that $\Delta W_{t}^{+}=\Delta W_{t}$ if $\Delta W_{t}>0$ and $\Delta W_{t}^{+}=0$ if $\Delta W_{t}<0$. Accordingly, the asymmetric EC model for the wholesale-farm price relationship is

$$
\begin{aligned}
\Delta W_{t}= & \alpha+\beta_{1} \Delta W_{t-1}+\beta_{2} \Delta W_{t-2}+\beta_{3} \Delta F_{t}+\beta_{4} \Delta F_{t-1} \\
& +\beta_{5} \Delta F_{t-2}+\beta_{6} \Delta W_{t-1}^{+}+\beta_{7} \Delta F_{t}^{+}+\beta_{8} \Delta F_{t-1}^{+} \\
& +\gamma\left(F_{t-1}-\nu W_{t-1}\right)+\sum_{i=1}^{11} \delta_{i} D_{i}+\varepsilon_{t}
\end{aligned}
$$

Finally, the wholesale price data are not available for some products, and the analysis is limited to study of the farm-retail price relationship. We use the following EC model specification for these price series

$$
\begin{aligned}
\Delta R_{t}= & \alpha+\beta_{1} \Delta R_{t-1}+\beta_{2} \Delta R_{t-2}+\beta_{3} \Delta F_{t}+\beta_{4} \Delta F_{t-1} \\
& +\beta_{5} \Delta F_{t-2}+\beta_{6} \Delta R_{t-1}^{+}+\beta_{7} \Delta F_{t}^{+}+\beta_{8} \Delta F_{t-1}^{+} \\
& +\gamma\left(F_{t-1}-v R_{t-1}\right)+\sum_{i=1}^{11} \delta_{i} D_{i}+\varepsilon_{t}
\end{aligned}
$$

In each case, the test for asymmetric price transmission is based on the null hypothesis $H_{0}: \beta_{7}=\beta_{8}=0$ (no asymmetry), which states that the downstream price change in the current period is not asymmetrically impacted by upstream price changes during the current or preceding period.

When feedback is found from downstream to upstream markets, we need to use a more extensive EC model of the price changes for those goods. For example, the wholesale price model with feedback from the retail sector is

$$
\begin{aligned}
\Delta W_{t}= & \alpha+\beta_{1} \Delta W_{t-1}+\beta_{2} \Delta W_{t-2}+\beta_{3} \Delta F_{t}+\beta_{4} \Delta F_{t-1} \\
& +\beta_{5} \Delta F_{t-2}+\beta_{6} \Delta W_{t-1}^{+}+\beta_{7} \Delta F_{t}^{+}+\beta_{8} \Delta F_{t-1}^{+}+\beta_{9} \Delta R_{t-1}^{+} \\
& +\beta_{10} \Delta R_{t-2}+\beta_{11} \Delta R_{t}^{+}+\beta_{12} \Delta R_{t-1}^{+}
\end{aligned}
$$




$$
+\gamma\left(W_{t-1}-v F_{t-1}-\lambda R_{t-1}\right)+\sum_{i=1}^{11} \delta_{i} D_{i}+\varepsilon_{t}
$$

The null hypothesis for this case is $\mathrm{H}_{0}: \beta_{7}=\beta_{8}=\beta_{11}=$ $\beta_{12}=0$, and rejection of the joint null hypothesis implies that the wholesale price response is significantly asymmetric due to the farm price changes or the retail price changes.

Finally, we find that the farm and retail milk price series are difference stationary but not cointegrated, so we use a first difference polynomial lag model similar to the one used by Boyd and Brorsen (1988):

$$
\begin{aligned}
\Delta R_{t}= & \alpha+\beta_{1} \Delta R_{t-1}+\beta_{2} \Delta R_{t-2}+\beta_{3} \Delta F_{t-1}^{+}+\beta_{4} \Delta F_{t-2}^{+}+\beta_{5} \Delta F_{t-1}^{-} \\
& +\beta_{6} \Delta F_{t-2}^{-}+\beta_{7} * \text { time }+\sum_{i=1}^{11} \delta_{i} D_{i}
\end{aligned}
$$

Here, time is a trend variable, and the test for asymmetric price transmission is based on the null hypothesis $H_{0}: \beta_{3}+\beta_{4}=\beta_{5}+\beta_{6}=0$.

Before presenting the estimation and testing results, we should note a number of minor model specification and estimation issues. First, traditional specifications of error correction models do not include current terms on the righthand-side of the model, but some of the authors in the asymmetric price transmission literature have not strictly followed this convention. The current terms are included on the righthand-side in order to capture intraperiod (i.e., within a given month) price relationships across market levels. Therefore, the fitted error correction specifications may exhibit simultaneity bias because the model contains potentially endogenous regressors. Accordingly, we use two-stage least squares (2SLS) to consistently estimate the EC models by including the predicted values for the current terms on the righthandside. The predicted values are derived from the estimated reduced-form equations.

Second, the number of lagged values included on the righthand-side of the error correction models is based on the Schwarz Bayesian Criterion (SBC). For each of the products considered in this study, two lagged values (i.e., two months) yield the lowest SBC statistic for the estimated asymmetric error correction models. Third, the EC model parameters may not be stable across these lengthy sample periods, and we use Chow tests to determine whether the coefficients in the EC models are different in the first and second halves of the sample peri- od. Finally, the ECM specifications and the associated hypothesis tests for asymmetric pricing only consider the short-run dynamics of price transmission. We could also extend the error correction term to account for the long-run dynamics of asymmetric adjustment, but we follow the existing literature and focus on the short-run dynamics because the possible causes of the phenomenon are generally associated with short-term pricing behavior.

\section{Estimation and Testing Results}

The monthly data for the beef, pork, egg, broiler, turkey, potato, tomato, lemon and milk prices at the farm, wholesale and retail price levels were obtained from USDA Economics and Statistics System (usda. mannlib.cornell.edu). For most of the products, the data sets have more than 240 observations (i.e., more than 20 years). Following the convention in this literature, we use nominal prices to conduct all of the statistical analysis in the paper. We present detailed information about the data sets in Table 1 and the Data Appendix at the end of the paper.

All of the prices series are non-stationary based on the ADF test outcomes, and all of the series are cointegrated except the milk prices. We also found no significant evidence of seasonal unit root exists for any of the agricultural products in this study. The Granger causality test results are presented in Table 2 . In general, the price series for each product exhibit the expected farmto-wholesale-to-retail causal structure, and significant feedback was observed in the pork, beef, eggs, turkey, and lemon markets. The Chow test results (not presented) provide moderate to strong evidence of significant structural change in each of the cases.

Finally, the set of results for the hypothesis tests of asymmetric price transmission are presented in Table 3, and we can note several outcomes. First, the pork data is the only price series that did not exhibit some form of significant asymmetric price transmission. This result is quite interesting given that the much of the previous literature has focused on pork prices, and other authors have found significant evidence of asymmetric price transmission. Second, the test results across market levels are mixed, and there is no clear pattern in the asymmetry test results for the different market levels. We tend to find stronger evidence in the wholesale-farm

Table 1. Summary of data sets

\begin{tabular}{lccll}
\hline & Sample period & Sample size & Units & Price series available \\
\hline Pork & Jan 1970 - Dec 2003 & 408 & cents per pound & Farm, wholesale, retail \\
Beef & Jan 1970 - Dec 2003 & 408 & cents per pound & Farm, wholesale, retail \\
Broilers & Jan 1980 - Dec 2000 & 252 & cents per pound & Farm, wholesale, retail \\
Eggs & Jan 1982 - Dec 2000 & 228 & cents per pound & Farm, wholesale, retail \\
Turkey & Jan 1979 - Dec 2000 & 264 & cents per pound & Farm, wholesale, retail \\
Potatoes & Jan 1985 - Dec 2001 & 204 & cents per pound & Farm, retail \\
Milk & Jan 1980 - Dec 1998 & 228 & dollars per half gallon & Farm, retail \\
Tomatoes & Jan 1980 - Dec 2001 & 264 & cents per pound & Farm, retail \\
Lemon (South) & Jan 1985 - Dec 1990 & 72 & dollars per 38 pound carton & Farm, wholesale, retail \\
Lemon (West) & Jan 1985 - Dec 1990 & 72 & dollars per 38 pound carton & Farm, wholesale, retail \\
Lemon (N Central) & Jan 1985 - Dec 1990 & 72 & dollars per 38 pound carton & Farm, wholesale, retail \\
\hline
\end{tabular}


Table 2. Causality and feedback test results

\begin{tabular}{|c|c|c|c|c|c|}
\hline & & \multicolumn{2}{|c|}{ Causality test } & \multicolumn{2}{|c|}{ Feedback test } \\
\hline & & Statistic & $\mathrm{P}$-value & Statistic & $\mathrm{P}$-value \\
\hline \multirow[t]{2}{*}{ Pork } & Farm to wholesale & 5.16 & 0.0061 & 1.01 & 0.3662 \\
\hline & Wholesale to retail & 70.20 & $<0.0001$ & 2.47 & 0.0855 \\
\hline \multirow[t]{2}{*}{ Beef } & Farm to wholesale & 5.35 & 0.0051 & 2.07 & 0.1276 \\
\hline & Wholesale to retail & 100.86 & $<0.0001$ & 16.78 & $<0.0001$ \\
\hline \multirow[t]{2}{*}{ Broilers } & Farm to wholesale & 2.02 & 0.1349 & 0.63 & 0.5344 \\
\hline & Wholesale to retail & 25.76 & $<0.0001$ & 1.40 & 0.2475 \\
\hline \multirow[t]{2}{*}{ Eggs } & Farm to wholesale & 2.84 & 0.0608 & 4.53 & 0.0118 \\
\hline & Wholesale to retail & 43.92 & $<0.0001$ & 0.82 & 0.4431 \\
\hline \multirow[t]{2}{*}{ Turkey } & Farm to wholesale & 11.01 & $<0.0001$ & 42.03 & $<0.0001$ \\
\hline & Wholesale to retail & 2.59 & 0.0767 & 11.78 & $<0.0001$ \\
\hline Potatoes & Farm to retail & 29.25 & $<0.0001$ & 4.25 & 0.0156 \\
\hline Milk & Farm to retail & 7.95 & 0.0005 & 2.32 & 0.1007 \\
\hline Tomatoes & Farm to retail & 177.44 & $<0.0001$ & 1.27 & 0.2820 \\
\hline \multirow[t]{2}{*}{ Lemon (South) } & Farm to wholesale & 15.79 & $<0.0001$ & 2.03 & 0.1402 \\
\hline & Wholesale to retail & 3.91 & 0.0250 & 1.00 & 0.3752 \\
\hline \multirow{2}{*}{ Lemon (West) } & Farm to wholesale & 4.57 & 0.0140 & 4.31 & 0.0175 \\
\hline & Wholesale to retail & 8.83 & 0.0004 & 1.74 & 0.1835 \\
\hline Lemon & Farm to wholesale & 7.49 & 0.0012 & 4.67 & 0.0127 \\
\hline (North Central) & Wholesale to retail & 10.30 & 0.0001 & 5.17 & 0.0083 \\
\hline
\end{tabular}

Table 3. Price asymmetry test results

\begin{tabular}{|c|c|c|c|c|}
\hline & Market level & Period & Statistic & P-value \\
\hline \multirow[t]{4}{*}{ Pork } & \multirow[t]{2}{*}{ Farm to wholesale } & 1970 to 1986 & 0.02 & 0.8961 \\
\hline & & 1987 to 2003 & 0.43 & 0.5137 \\
\hline & \multirow{2}{*}{ Wholesale to retail } & 1970 to 1986 & 0.06 & 0.8120 \\
\hline & & 1987 to 2003 & 0.57 & 0.4527 \\
\hline \multirow[t]{4}{*}{ Beef } & \multirow[t]{2}{*}{ Farm to wholesale } & 1970 to 1986 & 26.67 & 0.0001 \\
\hline & & 1987 to 2003 & 8.57 & 0.0002 \\
\hline & \multirow[t]{2}{*}{ Wholesale to retail } & 1970 to 1986 & 2.06 & 0.1292 \\
\hline & & 1987 to 2003 & 5.86 & 0.0031 \\
\hline \multirow[t]{4}{*}{ Broilers } & \multirow{2}{*}{ Farm to wholesale } & Jan 1980 to Jun 1990 & 14.54 & 0.0001 \\
\hline & & Jul 1990 to Dec 2000 & 4.90 & 0.0084 \\
\hline & \multirow[t]{2}{*}{ Wholesale to retail } & Jan 1980 to Jun 1990 & 3.43 & 0.0342 \\
\hline & & Jul 1990 to Dec 2000 & 1.42 & 0.2436 \\
\hline \multirow[t]{4}{*}{ Eggs } & \multirow[t]{2}{*}{ Farm to wholesale } & Jan 1982 to Jun 1991 & 10.48 & 0.0001 \\
\hline & & Jul 1991 to Dec 2000 & 7.22 & 0.0010 \\
\hline & \multirow[t]{2}{*}{ Wholesale to retail } & Jan 1982 to Jun 1991 & 6.21 & 0.0025 \\
\hline & & Jul 1991 to Dec 2000 & 6.03 & 0.0029 \\
\hline \multirow[t]{4}{*}{ Turkey } & \multirow{2}{*}{ Farm to wholesale } & 1979 to 1989 & 25.14 & 0.0001 \\
\hline & & 1990 to 2000 & 6.86 & 0.0013 \\
\hline & \multirow[t]{2}{*}{ Wholesale to retail } & 1979 to 1989 & 5.90 & 0.0032 \\
\hline & & 1990 to 2000 & 0.24 & 0.7842 \\
\hline \multirow{2}{*}{ Potatoes } & \multirow{2}{*}{ Farm to retail } & Jan 1985 to Jun 1993 & 3.61 & 0.0318 \\
\hline & & Jul 1993 to Dec 2001 & 2.76 & 0.0691 \\
\hline \multirow[t]{2}{*}{ Tomatoes } & \multirow[t]{2}{*}{ Farm to retail } & 1980 to 1990 & 3.33 & 0.0396 \\
\hline & & 1991 to 2001 & 8.02 & 0.0006 \\
\hline Milk & Farm to retail & Jan 1980 - Dec 1998 & 0.76 & 0.3829 \\
\hline \multirow[t]{2}{*}{ Lemon (South) } & Farm to wholesale & Jan 1985 - Dec 1990 & 0.87 & 0.4227 \\
\hline & Wholesale to retail & Jan 1985 - Dec 1990 & 5.98 & 0.0036 \\
\hline \multirow[t]{2}{*}{ Lemon (West) } & Farm to wholesale & Jan 1985 - Dec 1990 & 3.78 & 0.0263 \\
\hline & Wholesale to retail & Jan 1985 - Dec 1990 & 0.55 & 0.5811 \\
\hline \multirow{2}{*}{$\begin{array}{l}\text { Lemon } \\
\text { (North Central) }\end{array}$} & Farm to wholesale & Jan 1985 - Dec 1990 & 4.63 & 0.0121 \\
\hline & Wholesale to retail & Jan 1985 - Dec 1990 & 0.05 & 0.9523 \\
\hline
\end{tabular}

price relationship, but this outcome is not uniform within the sample (e.g., the lemon market in the Southern US). Third, the evidence does not exhibit a strong temporal pattern. Although some markets indicate stronger evidence of asymmetric pricing in the earlier periods, this outcome is also not uniform (e.g., the beef retailwholesale and tomato cases are counter-examples).

\section{META-ANAIYSIS OF ASYMMETRY TEST RESULTS}

To resolve some of the uncertainty present in the asymmetric pricing test results, we estimate a meta-analytic regression model based on these test results. The dependent variable for the regression model is the observed p-value for the asymmetry test statistic, and 
the non-constant explanatory variables include dummy variables for wholesale-farm test outcomes and sample periods occurring before 1990. There are also four product-specific dummy variables for pork, beef, poultry (broilers, turkey, and eggs), and lemons, which implies that the base group for comparison is potatoes, tomatoes, and milk. We also include a continuous variable that represents the length of the sample period.

The ordinary least squares (OLS) estimation results for the meta-analytic model are presented in Table 4 . Although the sample is relatively small $(\mathrm{N}=31)$, the fitted model explains about $55 \%$ of the observed variation in the p-values. All but one of the signs on the estimated coefficients agree with expectations, and three of the estimates are significantly different from zero at the $10 \%$ level (wholesale-farm, pork, and lemon). In particular, the wholesale-farm cases have $\mathrm{p}$-values that are 0.163 less than the base group, which agrees with our observation that the wholesale-farm relationship tends to have more significant asymmetric price transmission. The negative coefficient on the pre-1990 dummy variable also supports our observation that asymmetric pricing is more prominent in the early sub-sample periods, but this effect is very small (i.e., p-values are roughly 0.01 smaller in the pre-1990 period).

The pork and lemon p-values tend to be 0.44 and 0.54 above the base group (respectively), and both results are statistically significant. The beef $p$-values are smaller than the base $\mathrm{p}$-values by 0.19 , and the poultry $\mathrm{p}$-values are larger than the base $\mathrm{p}$-values by 0.11 . However, these estimates are not significantly different from zero. Finally, we note that the evidence associated with the sample period length is contrary to expectations — in general, we expect that longer samples may exhibit more evidence of asymmetric price transmission due to the larger number of complete price cycles in the data. To the contrary, the estimated meta-analytic model indicates that the test $\mathrm{p}$-value is expected to increase by 0.04 for each year added to the sample period. The estimate is not statistically significant, but the $\mathrm{p}$-value associated with this coefficient is moderately small at 0.19 .

Table 4. Meta-Analysis Regression Results

\begin{tabular}{lrrc}
\hline & \multicolumn{1}{l}{ OLS } \\
& Estimate & t-ratio & p-value \\
\hline Intercept & -0.346 & -0.955 & 0.350 \\
Farm-wholesale & -0.163 & -1.746 & 0.094 \\
Pre-1990 & -0.011 & -0.110 & 0.914 \\
Pork & 0.446 & 1.984 & 0.059 \\
Beef & -0.190 & -0.844 & 0.408 \\
Poultry & 0.112 & 0.804 & 0.430 \\
Lemon & 0.540 & 2.399 & 0.025 \\
Sample & 0.0386 & 1.348 & 0.191 \\
\hline
\end{tabular}

$\mathrm{R}^{2}=0.545$

Adjusted $\mathrm{R}^{2}=0.407$

$\mathrm{N}=31$

\section{CONCLUSION}

This paper uses estimated EC models to test for asymmetric price transmission in the observed price data for several US agricultural product markets. The test results suggest that strong price asymmetry exists in the markets for beef, broilers, eggs, turkey, potatoes, tomatoes and lemons (all three regions). Overall, the statistically significant evidence of asymmetric price transmission was found in the farm-to-wholesale price relationship or the wholesale-to-retail price relationship for some commodities, and the test results were significant in both market levels for some products.

The meta-analysis based on the test p-values helped to clarify some of the observed patterns in the test results. In particular, the evidence of asymmetric price transmission is highly product specific, and this appears to be the strongest common relationship in the combined test results. Further, we found significantly stronger evidence of asymmetric pricing in farm-towholesale markets and moderate evidence of asymmetries in the earlier years of our sample periods (i.e., before 1990). Finally, we found modest evidence of less asymmetric price transmission in longer samples, which is not statistically significant but still contrary to our expectations.

Before concluding, we should acknowledge that there are certain data limitations of this study. First, we should keep in mind that the asymmetry test depends on the error correction model specifications. Second, structural change is statistically significant for some midsample regime changes, but the asymmetry test results may be affected if the actual regime change occurs elsewhere in the sample period. Third, researchers have expressed concerns about the quality of some price data available from federal sources. For example, much of the farm and wholesale trade for livestock and other farm products is covered by contracted sales that may not be adequately represented in survey data, especially in the past few years. Also, the retail meat price data may not fully reflect price specials or discounts so that the reported monthly price data over-estimate the actual retail meat prices.

\section{REFERENCES}

Abdulai, A. 2002 Using Threshold Cointegration to Estimation Asymmetric Price Transmission in the Swiss Pork Market. Applied Economics, 34: 679-687

Azzam, A. 1999 Asymmetry and Rigidity in Farm-Retail Price Transmission. Amer. J. Agr. Econ., 81: 525-533

Bacon, R. 1991 Rockets and Feathers: The Asymmetric Speed of Adjustment of UK Retail Gasoline Prices to Cost Changes. Energy Economics, XIII: 211-218

Bailey, D., and B. W. Brorsen 1989 Price Asymmetry in Spatial Fed Cattle Markets. Western Journal of Agricultural Economics, 14: 246-252

Balke, N. S., Brown, S. P. A., and M. K. Yücel 1998 Crude Oil and Gasoline Prices: An Asymmetric Relationship? Economic Review, First Quarter: 2-11

Balke, N. S., Brown, S. P. A., and M. K. Yücel 2002 Oil Prices, Shocks, and the US Economy: Where Does the Asymmetry Originate? The Energy Journal, 23: 27-52 
Ball, L., and G. Mankiw 1994 Asymmetric Price Adjustment and Economic Fluctuations. The Economic Journal, 104: $247-261$

Bénabou, R., and R. Gertner 1993 "Search with Learning from Prices - Does Increased Inflationary Uncertainty Lead to Higher Markups? Review of Economic Studies, 60: 69-93

Bernard, J., and L. Willett 1996 Asymmetric Price Relationships in the US Broiler Industry. Journal of Agricultural and Applied Economics, 28: 279-289

Bettendorf, L., S. A. Geest, and M. Varkevisser 2003 Price Asymmetry in the Dutch Retail Gasoline Market. Energy Economics, 25: 669-689

Blinder, A. 1982 Inventories and Sticky Prices: More on the Microfoundations of Macroeconomics. American Economic Review, 72: 334-348

Blinder, A., E. Canetti, D. Lebow, and J. Rudd 1998 Asking About Prices: A New Approach to Understanding Price Stickiness. New York, NY: Russell Sage Foundation

Borenstein, S., A. Cameron, and R. Gilbert 1997 Do Gasoline Prices Respond Asymmetrically to Crude Oil Prices. Quarterly Journal of Economics, 112: 305-339

Boyd, M., and B. W. Brorsen 1985 Dynamic Relationship of Weekly Prices in the United States Beef and Pork Marketing Channels. Canadian Journal of Agricultural Economics, 33: $331-342$

Boyd, M., and B. W. Brorsen 1988 Price Asymmetry in the US Pork Marketing Channel. North Central Journal of Agricultural Economics, 10: 103-109

Brown, S., and M. Yücel 2000 Gasoline and Crude Oil Prices: Why the Asymmetry? Economic and Financial Review, Third Quarter: 23-29

Bunte, F., and J. Peerlings 2003 Asymmetric Price Transmission Due to Market Power in the Case of Supply Shocks. Agribusiness, 19: 19-28

Dickey, D. A., and W. A. Fuller 1979 Distribution of Estimators for Autoregressive Time Series with a Unit Root. J. Am. Stat. Assoc., 74: 427-431

Dickey, D., D. Hasza, and W. Fuller 1984 Testing for Unit Roots in Seasonal Time Series. Journal of the American Statistical Association, 79: 355-367

Eckert, A. 2002 Retail Price Cycles and Response Asymmetry. Canadian Journal of Economics, 35: 52-77

Engle, R. F., and C. W. J. Granger 1987 Co-integration and Error Correction: Representation, Estimation, and Testing. Econometrica, 55: 251-276

Gardner, B. 1975 The Farm-Retail Price Spread in a Competitive Food Industry. Amer. J. Agr. Econ., 57: 399409

Goodwin, B., and M. Holt 1999 Price Transmission and Asymmetric Adjustment in the US Beef Sector. Amer. J. Agr. Econ., 81: 630-637

Goodwin, B., and D. Harper 2000 Price Transmission, Threshold Behavior, and Asymmetric Adjustment in the US Pork Sector. Journal of Agricultural and Resource Economics, 32: 543-553

Hahn, W. 1990 Price Transmission Asymmetry in Pork and Beef Markets. Journal of Agricultural Economic Research, 42: 21-30

Kinnucan, H. W. and O. D. Forker 1987 Asymmetry in FarmRetail Price Transmission for Major Dairy Products. Amer. J. Agr. Econ., 69: 285-292

Kovenock, D., and K. Widdows 1998 Price Leadership and Asymmetric Price Rigidity. European Journal of Political Economy, 14: 167-187

Marsh, J. M. and G. W. Brester 2004 Wholesale-Retail Marketing Margin Behavior in the Beef and Pork Industries. Journal of Agricultural and Resource Economics, 29: $45-64$

Miller, D. J. and M. L. Hayenga 2001 Price Cycles and Asymmetric Price Transmissions in the U.S. Pork Market. Amer. J. Agr. Econ., 83: 555-562

Polaskas, T. 1995 Statistical Analysis of Price Transmission in the European Union. Journal of Agricultural Economics, 46: $60-69$

Powers, N. 1995 Sticky Short-Run Prices and Vertical Pricing: Evidence from the Market for Iceberg Lettuce. Agribusiness, 11: 57-75

Reagan, P. B., and M. L. Weitzman 1982 Asymmetries in Price and Quantity Adjustments by the Competitive Firm. Journal of Economic Theory, 27: 410-420

Reynolds, S. 1982 Limit Pricing, Conjectural Variations, and Entry. Economic Letters, 9: 195-199

Romain, R., M. Doyon, and M. Figon 2002 Effects of State Regulation on Marketing Margins and Price Transmission Asymmetry: Evidence from the New York City and Upstate New York Fluid Milk Markets. Agribusiness, 18: 301-315

Said, S. E., and D. A. Dickey 1984 Testing for Unit Roots in Autoregressive-Moving Average Model of Unknown Order. Biometrika, 71: 599-607

Schroeder, T. C., and M.L. Hayenga 1987 Short-Term Vertical Market Price Interrelationships for Beef and Pork. North Central Journal of Agricultural Economics, 9: 171-180

Schroeder, T. 1988 Price Linkages between Wholesale and Retail Pork Cuts. Agribusiness, 4: 359-369

Serra, T., and B. Goodwin 2003 Price Transmission and Asymmetric Adjustment in the Spanish Dairy Sector. Applied Economics, 35: 1889-1899

Von Cramon-Taubadel, S. 1998 Estimating Asymmetric Price Transmission with the Error Correction Representation: An Application to the German Pork Market. European Review of Agricultural Economics, 25: 1-18

Willett, L., M. Hansmire, and J. Bernard 1997 Asymmetric Price Response Behavior of Red Delicious Apples Agribusiness, 13: 649-658

\section{DATA APPENDIX}

\section{Beef and Pork Prices (cents per pound)}

The USDA Economic Research Service (ERS) uses a standard animal to calculate the beef and pork price spreads. This standard animal is cut up in a fixed way at the packing plant, and its wholesale cuts are in turn cut up in a standard way at the retail level. To compare the total value of the animal at the farm with the total value of the animal at the wholesale and retail levels, ERS calculates the price spreads on a per-pound-of-retail product basis. A pound of retail beef requires 2.40 pounds of the standard live steer and 1.14 pounds of wholesale beef. For hogs, the conversion factors are 1.869 pounds of live hog per pound of retail cuts and 1.04 pounds of wholesale cuts per pound of retail cuts

\section{Egg, Broiler and Turkey Prices (cents per pound)}

Farm, wholesale, and retail egg prices represent Grade A large egss (excludes hatching eggs). Broiler farm prices are the average price received by farmers, wholesale prices are 12 -city composite wholesale prices for ready-to-cook broilers, and retail prices are the composite retail prices for young chickens. Turkey farm prices are the live weight prices received by farmers, wholesale prices are a weighted average for three representative regions (central, eastern and western, where the central region receives twice the weight of the other two regions in the averages), and retail prices are the average U.S. retail prices for whole frozen birds.

\section{Lemon Prices (dollars per 38 pound carton)}

The farmer (grower) price is from USDA's National Agricultural Statistics Service (NASS) database. The wholesale prices are from USDA's Agricultural Marketing Service (AMS) Market News Group, which surveys terminals around the country on a daily basis. The retail prices come from the U.S. Bureau of Labor Statistics (BLS) and are part of the monthly BLS consumer price database. The retail lemon prices are available for three regions in the US (West, South and North Central). 


\section{Potato and Tomato Prices (cents per pound)}

Farm prices for potatoes and tomatoes are average shippingpoint prices calculated by USDA/NASS using information reported by the Market News Service of USDA/AMS.

Retail prices are collected for use in calculating the Consumer Price Index (CPI) for 87 urban areas and from about 23,000 retail and service establishments in the US. Comparable wholesale price data for potatoes and tomatoes are not available.

\section{Milk Prices (dollars per half gallon)}

Farm milk prices are prices received by farmers for milk eligible for fluid use, and retail prices are fortified retail prices for fresh whole milk. Both price series are collected by BLS, and there is no comparable wholesale milk price series available. 